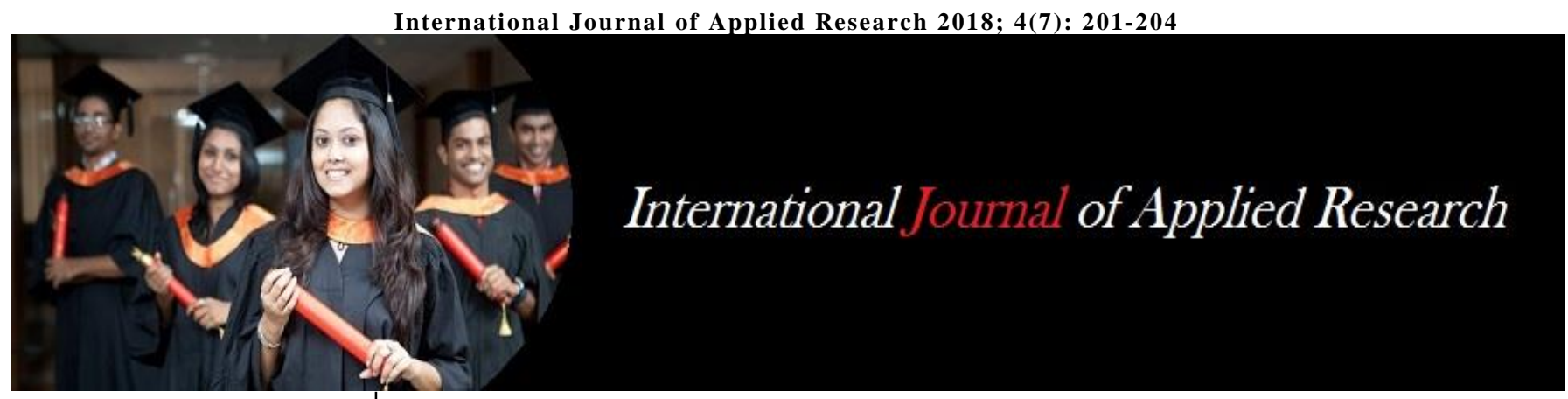

ISSN Print: 2394-7500

ISSN Online: 2394-5869

Impact Factor: 5.2

IJAR 2018; 4(7): 201-204

www.allresearchjournal.com

Received: 06-05-2018

Accepted: 16-06-2018

\section{Dr. Anjali Arora}

Associate Professor,

Department of Commerce, Sri

Aurobindo College, University

of Delhi, Delhi, India

Bunny Singh Bhatia

Assistant Professor,

Department of Commerce, Sri Aurobindo College, University of Delhi, Delhi, India
Correspondence

Dr. Anjali Arora

Associate Professor,

Department of Commerce, Sri

Aurobindo College, University

of Delhi, Delhi, India

\title{
Interlinkages between FDI Inflow and Economic Growth
}

\section{Dr. Anjali Arora and Bunny Singh Bhatia}

DOI: https://doi.org/10.22271/allresearch.2018.v4.i7c.9083

Abstract

The paper investigates into the connection between foreign direct investment (FDI) on the one hand and economic growth (GDP) on the other, over a long period of time, almost half a century, from 1970 to 2017. The key insights derived from this study are, firstly, that there is long run association between FDI and economic growth, secondly, FDI inflow causes and affects economic growth, and finally that economic growth does not spur FDI at national level. However at the state level, economic growth plays pivotal role in the location of FDI which implies that the selection of state is done on the basis of economic growth, that is Gross State Domestic Product (GSDP). Therefore in the long run and at the national level, policies should be directed towards the encouragement of FDI inflow, in order to boost economic growth. States should enhance their infrastructure and economic growth in order to enhance their share in total FDI.

Keywords: Foreign direct investment, FDI inflow, GDP, economic growth, granger causality

\section{Introduction}

FDI is critical to a country's success. It improves the efficiency of the economy. The need for FDI is determined by a country's saving and investment rates, and it is necessary to bridge the gap between investment and savings. FDI has a key function to play in that the shortfall in savings for the purpose of investment is taken care of by FDI. (Dwivedi \& Kumar, 2017) ${ }^{[1]}$. Over the last 20 years, the world has appreciated the ability of foreign direct investment which in layman's terms, refers to net foreign inflows of cash into the country which needs and solicits it, which helps it to progress economically. (Noorbakhsh et al., 2001) ${ }^{[2]}$. It is a form of investment in which foreign money are invested in an entity that operates in a different country, that is, not the one to which the investor belongs. A considerable amount of work on the drivers of FDI in emerging economies emphasises on the significance of infrastructure, human capital and skilled labour, stable macroeconomic environment, with strong institutions in place. Furthermore, inflows of foreign direct investment (FDI) have accelerated economic expansion and growth in a number of economies. Despite extensive studies conducted into the association between FDI on one hand and economic growth on the other, the findings are sometimes contradictory. This paper seeks to investigate the relationship between FDI and Gross Domestic Product (GDP).

\section{The following are the research questions which have been examined}

1. Whether there exists a long run association between FDI inflow and GDP (which represents Economic Growth)?

2. Does FDI inflow cause economic growth?

3. Does Economic growth cause and spur FDI inflow?

4. Does the relationship of FDI inflow with Economic growth exist across the states?

\section{Review of literature}

Brozenstein and Gregorio (1998) conducted a study on 69 countries for a period of 2 decades to discern the effect of FDI on countries economic growth. 
According to their study FDI helps in increasing economic growth by transfer of technology but the developing countries can reap the benefits of this sophisticated technology only if they are endowed with basic human capital to be able to understand and use and absorb this technology ${ }^{[3]}$. Carkovic, M., \& Levine, R. (2005), taking a panel of data of 72 countries over a period 1960-95 found that FDI does not independently effect on growth in a positive manner. FDI along with other growth determinants may spur economic growth, but not independently ${ }^{[4]}$. Similarly Bengoa, M \& Sanchez-Robles, B (2003) observe in their work that for FDI to have a productive effect on economic growth there should be some preconditions in the economy like economic stability, liberalisation of capital markets and sufficient amount of human capital ${ }^{[5]}$. The importance of human capital has also been reiterated by $\mathrm{Li}$, X \& Liu, X (2005), taking a panel dataset of 84 countries for a span of 29 years [6]. Bloomstrom et al. (1994), in an analysis involving 78 emerging economies also establish the effective role of FDI in having a positive outcome on growth only for countries having high income and trade openness ${ }^{[7]}$. Batten, J., \& Vo, X. (2009) while analysing the relation of foreign direct investment with economic progress and growth, bring forth the view that FDI tends to have a beneficial impact on growth in case the nation possess features such as good education attainment and good institutions in place in the area of trade and stock markets ${ }^{[8]}$. Chowdhury, A., \& Mavrotas, G. (2006) examine the causative relationship of FDI and economic growth, which of these two explains the occurrence of the other, by using econometric techniques for three countries of the developing world, namely Chile, Thailand and Malaysia which receive a good amount of FDI but having different policy regimes. According to them in case of Chile GDP causes FDI whereas in the other two countries studied the causality was bi-directional ${ }^{[9]}$.

Hansen, H., \& Rand, J. (2006) used Granger causality tests for assessing the causality relationship between FDI received and GDP for a sample of over 30 countries for over 30 years. They found a bi-directional relationship but FDI had a lasting influence on GDP while it was not the other way round indicating that FDI impacted GDP through long term technology \& knowledge transfer ${ }^{[10]}$.

Herzer, D., \& Klasen, S. (2008) challenge the belief that FDI has an impact on GDP depending upon the level and extent of education, the measure to which the economy is open and whether the financial market is developed. They don't find FDI having a conclusive effect on growth in any of the country in their sample ${ }^{[11]}$. According to Alguacil, Cuadros, \& Orts, (2011) FDI can contribute to growth if favourable political and economic policies are in place which will increase the absorptive capacity of FDI ${ }^{[12]}$. Jude, C., \& Levieuge, G. (2015) show that FDI helps in growth provided the right kind of institutions exist. Hence institutional reforms are a precondition if FDI is to contribute to the growth and development of the country of destination ${ }^{[13]}$.
Nunnenkamp, P., \& Stracke, R. (2007) in their analysis of the possible factors which attract FDI in the states of India, they find that foreign investors choose locations which are doing well in per capita income, infrastructure and skilled labour. FDI also has a positive effect on growth only in those states which are richer and does not appear to benefit less advanced states ${ }^{[14]}$.

Gupta (2017) while exploring a possible relation between FDI \& presence of human capital in the distribution of FDI among states of India found no relation between the two variables. She found the market size which is measured by the State gross domestic product along with infrastructure and cheap labour as factors having a significant effect ${ }^{[15]}$. Kaur, Yadav, \& Gautam (2013) in their study in the Indian context argue that good infrastructure in the form of transportation, telecommunications and electricity provide a favourable environment to do business to the foreign investors ${ }^{[16]}$. Chatterjee, S., Mishra, P., \& Chatterjee, B. (2013) while identifying the factors which are responsible for interstate variations in FDI they point out to the profitability of the existing firms as the main determining factor for influencing FDI rather than the presence of infrastructure which is touted to be the most important by many scholars ${ }^{[17]}$.

\section{Data Analysis and Interpretation}

In our study, GDP and GDP per capita are used to represent economic growth. We have collected annual data of GDP, FDI and GDP per capita during 1970 to 2017 from International Monetary Fund's 'Balance of Payments Statistics Yearbook', 'World Bank national accounts data', and 'OECD National Accounts data files'. Firstly we have taken the log value of all the variables, since we have used time series dated data. To check stationarity of our data, Augmented Dickey Fuller test is conducted. All the variables are non- stationary at level value. Therefore, variables were converted into first difference. Table 1 shows that null hypothesis of unit root is rejected at $p$ value 0.00 for each variables. Therefore, log value of GDP, FDI and GDP per capita are stationary at first difference are of integrated order I (1)

Table 1: Augmented Dickey-Fuller test statistic

\begin{tabular}{|c|c|c|}
\hline Hypothesis & t-Statistic & Prob \\
\hline Null Hypothesis: D(LNFDI) has a unit root & -6.794 & 0.00 \\
\hline Null Hypothesis: D(LNGDP) has a unit root & -6.437 & 0.00 \\
\hline Null Hypothesis: D(LNPCGDP) has a unit root & -6.389 & 0.00 \\
\hline
\end{tabular}

*’MacKinnon (1996)" one-sided p-values.

Author's Calculation

By Using VAR Lag Order Selection Criteria, we have selected Lag 1 at which further analysis has been conducted. As most of test including 'FPE' (Final prediction error), 'SC', (Schwarz information criterion) and 'HQ' (HannanQuinn information criterion) suggest that lag 1 is the most appropriate test.

Table 2: Selection of Lag criteria (VAR)

\begin{tabular}{|c|c|c|c|c|c|c|}
\hline Lag & LogL & LR & FPE & AIC & SC & HQ \\
\hline 0 & -76.40059 & NA & 0.460392 & 4.900037 & 4.991645 & 4.930402 \\
\hline 1 & 17.48578 & 170.1690 & $0.001674^{*}$ & -0.717861 & $-0.443036^{*}$ & $-0.626764^{*}$ \\
\hline 2 & 18.14842 & 1.118210 & 0.002071 & -0.509276 & -0.051234 & -0.357448 \\
\hline
\end{tabular}




\begin{tabular}{|l|l|l|l|l|l|l|}
\hline 3 & 18.43760 & 0.451842 & 0.002635 & -0.277350 & 0.363909 & -0.064791 \\
\hline 4 & 20.24246 & 2.594480 & 0.003074 & -0.140153 & 0.684323 & 0.133137 \\
\hline
\end{tabular}

"Endogenous variables: LNGDP LNFDI

Exogenous variables: $\mathrm{C}$

* indicates lag order selected by the criterion

LR stands for sequential modified LR test statistic (each test at $5 \%$ level)

FPE stands for Final prediction error

AIC stands for Akaike information criterion

SC stands for Schwarz information criterion

HQ stands for Hannan-Quinn information criterion"

Table 3: Results from the Johansen Cointegration Trace and the Maximum Eigenvalue test

\begin{tabular}{|c|c|c|c|}
\hline Test & Hypothesized relations & Trace test statistic & Probability \\
\hline \multirow{2}{*}{ Trace test } & None ${ }^{*}$ & 16.02467 & 0.0115 \\
\cline { 2 - 4 } & At most 1 & 0.962374 & 0.3785 \\
\hline \multirow{2}{*}{ Maximum Eigenvalue test } & None $*$ & 15.06230 & 0.0101 \\
\cline { 2 - 4 } & At most 1 & 0.962374 & 0.3785 \\
\hline
\end{tabular}

The table reports results from Johansen cointegration Trace tests, and Maximum Eigenvalue tests, ** denotes significance at the 5\% level, and $*$ at the $10 \%$ level

Compiled by Author

Table 3 shows that there is one co-integrating equation between FDI inflow and GDP since Trace test indicates one cointegrating eqn(s) at the 0.05 level and At the 0.05 threshold, the max-eigenvalue test suggests one cointegrating equation. It implies that there is evidence of long-run association between FDI inflow and Economic growth.

In order to check short run causality between FDI inflow and GDP we employed Granger causality test and the results are shown in Table 4. At 5\% level of significance FDI is granger causing both GDP and GDP per capita at lag 1. On the other hand GDP does not have any influence on the FDI. Hence we say that the direction of causality is from FDI to GDP and not otherwise.

The key insights derived from this study: Firstly, there is long run association between FDI and Economic growth. Secondly, FDI inflow causes and affects Economic growth. Thirdly, Economic growth does not spur FDI at national level. However, at the state level, Economic growth plays pivotal role in the selection of a particular state for FDI.

Table 4: Results from Granger Causality Test

\begin{tabular}{|c|c|c|}
\hline Granger-Causality test with intercept & Test statistic & p-value \\
\hline LNGDP does not Granger Cause LNFDI & $3.10962 *$ & 0.0851 \\
\hline LNFDI does not Granger Cause LNGDP & $4.38451 * *$ & 0.0423 \\
\hline LNPCGDP does not Granger Cause LNFDI & 1.79739 & 0.1872 \\
\hline LNFDI does not Granger Cause LNPCGDP & $4.25613 * *$ & 0.0453 \\
\hline
\end{tabular}
Research Outcome * significance at 10\% level, ** significance at
\% level, *** significance at 1\% level

The following model was used to examine the association between FDI inflows and economic growth at the provincial level. The cross sectional data is considered for the year 2017 was considered for the state wise analysis.

$\mathrm{Y}=\alpha+\beta 1 \mathrm{SGDP}+\beta 2$ Infrastructure index
The Significance F, 0.00 which indicates that the model is very well fitted. Adjusted R square ranges, 0.53, which shows that variations in dependent variable are explained by the models.

In the model, it was observed that infrastructure index is positively and significantly associated with the FDI inflow. The coefficient is significant at 5\% level. GDP of states is positively as well as significantly associated with the FDI inflow. In each model, GDP of states is positively and significantly associated with the FDI inflow.

Infrastructure in the form of road, rail and air transport, an efficient system of communication, telecommunications are important to avoid bottlenecks in the smooth functioning of business and hence it is given due importance by foreign investors while making investment decisions. We have taken it as a control variable while estimating the significance of GSDP as a determinant of FDI.

Table 5: State wise Relationship between Economic Growth and FDI inflow

\begin{tabular}{|c|c|c|}
\hline & \multicolumn{2}{|c|}{ Model 3 } \\
\hline & Coefficients & P value \\
\hline Intercept & -6.21 & 0.01 \\
\hline INFRASTRUCTURE INDEX (2016) & $0.052^{* *}$ & 0.05 \\
\hline GDP (2017) & $2.11^{* * *}$ & 0.00 \\
\hline Adjusted R square & \multicolumn{2}{|c|}{0.531} \\
\hline Significance F & \multicolumn{2}{|c|}{0.00} \\
\hline
\end{tabular}

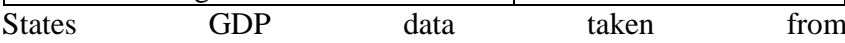

https://statisticstimes.com/economy/india/indian-states-gdp.php

Therefore we may say that states with strong infrastructure and Economic Growth tend to attract high FDI than other counterparts. Accordingly, Figure 1 demonstrates the structure of policy implications and its influence on Economic Growth. 


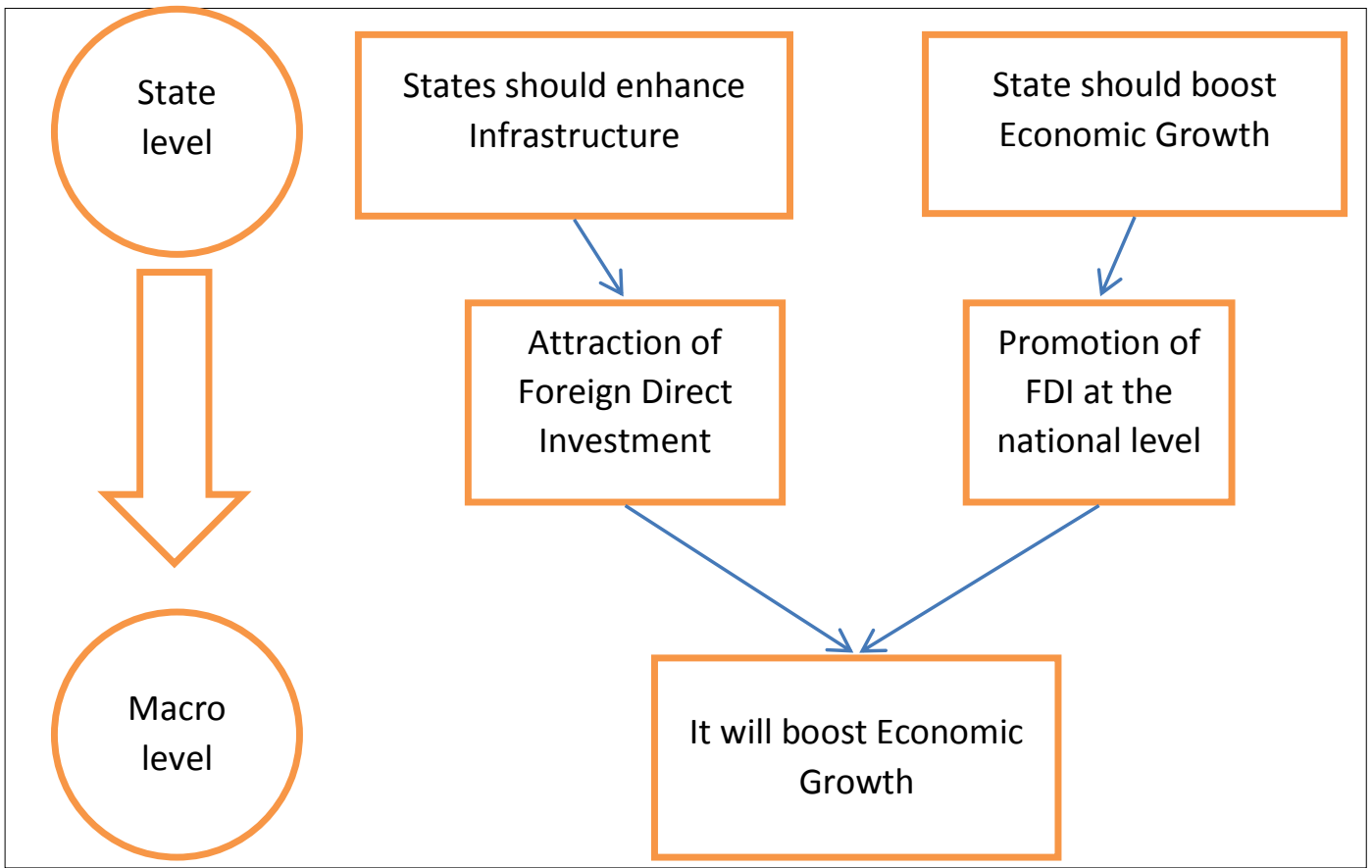

Fig 1: Structure of Policy implications and its impact on Economic Growth Research Outcome

\section{Conclusion}

Among the various determinants of FDI the location dimension considers availability of infrastructure, quality of human capital, a stable economic environment and low production costs as important. The institutional approach considers the prevalence of corruption and political instability to be the deterring factors and good quality of institutions and financial and fiscal incentives as encouraging factors for foreign investment. On the trade front factors such as size of the market and it's growth, how open the economy is, and factor endowments are important to the foreign investors ${ }^{[18]}$. Economic growth is the rise in the capability of a country/ states to put together more goods and services. At the national level it is represented by GDP and at the state level by GSDP. Ultimately the ability to produce depends upon the stock of capital, the quality of labour, the level of technology, institutions, infrastructure availability, and the rule of law. The state governments should take all these into consideration to improve their state's potential for economic growth. This will allure foreign investors to make investments in the states and lead to further growth as well as development in the national economy as a whole.

\section{References}

1. Dwivedi S, Kumar V. Role of Foreign Direct Investment and Indian Banking System. Journal of Bank Management \& Financial Strategies 2017;1(1):1-5.

2. Noorbakhsh F, Paloni A, Youssef A. Human capital and FDI inflows to developing countries: New empirical evidence. World development 2001;29(9):1593-1610

3. Borensztein E, De Gregorio J, Lee JW. How does foreign direct investment affect economic growth?. Journal of international Economics 1998;45(1):115-135.

4. Carkovic M, Levine R. Does foreign direct investment accelerate economic growth. Does foreign direct investment promote development, 2005, 195.

5. Bengoa M, Sanchez-Robles B. Foreign direct investment, economic freedom and growth: new evidence from Latin America. European journal of political economy 2003;19(3):529-545.

6. Li X, Liu X. Foreign direct investment and economic growth: an increasingly endogenous relationship. World development 2005;33(3):393-407.

7. Blomstrom M, Lipsey RE, Zejan M. What explains developing country growth? In W. J. Baumol (Ed.), Convergence of Productivity: Cross-National Studies and Historical Evidence (9th ed.). New York: Oxford University Press, Incorporated 1994.

8. Batten JA, Vo XV. An analysis of the relationship between foreign direct investment and economic growth. Applied Economics 2009;41(13):1621-1641.

9. Chowdhury A, Mavrotas G. FDI and growth: what causes what?. World economy 2006;29(1):9-19.

10. Hansen H, Rand J. On the causal links between FDI and growth in developing countries. World Economy 2006;29(1):21-41.

11. Herzer D, Klasen S. In search of FDI-led growth in developing countries: The way forward. Economic Modelling 2008;25(5):793-810.

12. Alguacil M, Cuadros A, Orts V. Inward FDI and growth: The role of macroeconomic and institutional environment. Journal of Policy Modeling 2011;33(3):481-496.

13. Jude C, Levieuge G. Growth effect of FDI in developing economies: the role of institutional quality 2015.

14. Nunnenkamp P, Stracke R. Foreign Direct Investment in Post-Reform India: Likely to work wonders for regional development? (No. 1375). Kiel Working Paper 2007.

15. Gupta V. Exploring the Relation between Human Capital and Foreign Direct Investment-Indian Context 2017.

16. Kaur M, Yadav SS, Gautam V. Foreign Direct Investment and Infrastructure Development: Evidence from India 2013.

17. Chatterjee S, Mishra P, Chatterjee B. Determinants of Inter-State Variations in FDI Inflows in India 2013.

18. Assunção S, Forte R, Teixeira A. Location determinants of FDI: a literature review 2011. 